\title{
REDUCED-IMPACT LOGGING BY ALLOCATING LOG-DECKS USING MULTI- OBJECTIVE EVOLUTIONARY ALGORITHM IN WESTERN AMAZON
}

\author{
Marcos Antonio Isaac Júnior ${ }^{2 *} \odot$, Bruno Henrique Groenner Barbosa ${ }^{3} \odot$, Lucas Rezende Gomide ${ }^{4}($ ) ,

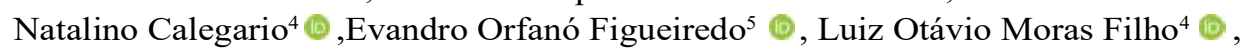 \\ Elliezer de Almeida Melo ${ }^{6}$ () and Daniel Dantas ${ }^{7}[0$
}

\footnotetext{
${ }^{1}$ Received on 11.10.2019 accepted for publication on 11.11.2020.

${ }^{2}$ Universidade Federal de Lavras, Doutorado em Engenharia Florestal, Lavras, MG - Brasil. E-mail: <maisaacjr@yahoo.com.br>.

${ }^{3}$ Universidade Federal de Lavras, Doutorado em Automática, Lavras, MG - Brasil. E-mail: <brunohb@gmail.com>.

${ }^{4}$ Universidade Federal de Lavras, Departamento de Ciências Florestais, Lavras, MG - Brasil E-mail: <lucasgomide@ufla.br>, <calegari@ ufla.br> and <lomf22@gmail.com>.

${ }^{5}$ Empresa Brasileira de Pesquisa Agropecuária, Rio Branco, AC - Brasil . E-mail: <evandro.figueiredo@embrapa.br > .

${ }^{6}$ Instituto Federal Goiano, Departamento Agronomia, Ceres, GO - Brasil. E-mail: <elliezermelo@hotmail.com>.

${ }^{7}$ Universidade Federal de Lavras,Programa de Pós-Graduação em Ciências Florestais, Lavras, MG - Brasil. E-mail: <dantasdaniel12@ yahoo.com.br>.

*Corresponding author.
}

\begin{abstract}
To reduce the damage caused by logging in the Amazon rainforest, new metaheuristics have been implemented and tested to ensure the sustainability of this economic segment. Therefore, this study aimed to compare alternatives for road sizing and log deck allocation. In a forest management unit, the skidding to log decks was evaluated in two different areas. To determine the skidding/log deck relation, georeferenced points were generated equally spaced every $50 \mathrm{~m}$. In area 1, the Integer Linear Programming (ILP) model and the Multi-Objective Evolutionary Algorithm (MOEA) were compared. In area 2, only the MOEA was considered. In both areas, these models were also compared to the current planning used in the forest management unit. Solutions were then generated to identify the best management alternative. In both areas, the MOEA showed greater efficiency regarding the processing time, as well as the reduction of log decks number and the road sizing. The multi-objective evolutionary approach assists the decision-making process, due to the presentation of alternatives based on Pareto-optimal solutions, making the choice more flexible and well supported.
\end{abstract}

Keywords: Forest management; Forest planning; Metaheuristics.

\section{EXPLORAÇÃO MADEIREIRA DE IMPACTO REDUZIDO POR MEIO DA ALOCAÇÃO DE PÁTIOS DE ESTOCAGEM DE MADEIRA USANDO ALGORITMO EVOLUTIVO MULTIOBJETIVO NA AMAZÔNIA OCIDENTAL}

\begin{abstract}
RESUMO - Com o objetivo de reduzir os danos causados pela exploração madeireira na floresta amazônica, novas meta-heurísticas vem sendo implementadas e testadas para garantir a sustentabilidade desse segmento economico. Assim, este trabalho tem como objetivo comparar alternativas para o dimensionamento de estradas e para alocação de pátios de estocagem de madeira. Em uma unidade de manejo florestal, o deslocamento da exploração de árvores para os pátios de estocagem de madeira foi avaliado em duas diferentes áreas. Para determinar a relação exploração de árvores / pátios de estocagem de madeira, pontos georreferenciados foram gerados igualmente espaçados a cada $50 \mathrm{~m}$. Na área 1, o modelo de Programação Linear Inteira (ILP) e o Algoritmo Evolutivo Multiobjetivo (MOEA) foram comparados. Na área 2, apenas o MOEA foi considerado. Em ambas as áreas, esses modelos também foram comparados com o planejamento executado na unidade de manejo florestal. Soluções foram geradas para identificar a melhor alternativa de manejo. Em ambas as áreas, o MOEA apresentou maior eficiência quanto ao tempo de processamento, bem como na redução do número de pátios de estocagem de madeira e no dimensionamento das estradas. A abordagem evolutiva multiobjetivo
\end{abstract}

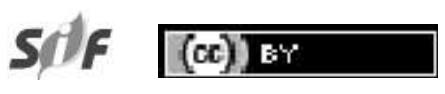

Revista Árvore 2021;45:e4506 http://dx.doi.org/10.1590/1806-908820210000006 
auxilia o processo de tomada de decisão, devido à apresentação de alternativas baseadas em soluções Paretoótimas, tornando a escolha mais flexível e bem fundamentada.

Palavras-Chave: Manejo florestal; Planejamento florestal; Meta-heurísticas.

\section{INTRODUCTION}

The activities planning involving the extraction of wood in the Amazon region are ruled by Normative Instruction No. 5/2006 (Brasil, 2006), of the Ministry of the Environment, and by Resolution No. 406/2009 (Brasil, 2009), of the National Environment Council. In general, these legal instruments seek to standardize criteria to ensure the sustainable management of these forests.

In this context, logging Brazilian Amazon consists of three phases: pre-exploratory, exploratory, and postexploratory. These phases allow the manager, in terms of forest planning, to reduce the impacts caused by logging. The damage caused by the lack of planning is: tree felling near the tree to be exploited due to lack of silvicultural treatments, construction of roads and patios more than necessary, lack of maintenance of forest exploitation area after harvest, among other factors. One problem in the Amazon, which involves decision making, is to determine the location of log decks allocation in the Annual Operational Plan.

Martinhago (2012) used Integer Linear Programming (ILP) method, based on the P-median technique, in Acre and Pará states in order to reduce the impacts of log deck allocation. However, this author identified that log deck allocation is a difficult task to be solved due to the large number of variables, which prevents the use of classical techniques such as ILP. Due to conflicting interests in the planning of the activity, natural resource managers can approach the problem of forest management as a multi-objective optimization problem, since such objectives are conservation and production.

The metaheuristics, or approximate methods, are part of a class of algorithms considered at a higher level than the heuristics, and can be applied in a range of problems and can be customized through logical rules of programming and components (Boussaïd et al., 2013). These algorithms are usually based on laws or behaviors found in nature and are successfully applied in several problems in forestry by researchers such as Steiguer et al. (2003), Ducheyne et al. (2006),
Fotakis et al. (2012), Gomide et al. (2013), Hernandez et al. (2014), Maier et al. (2014), Fotakis (2015), Liu and Lin (2015), and Álvarez-Miranda et al. (2018).

This study aimed to compare alternatives for road sizing and for log deck allocation, in order to reduce the impacts of logging on the Amazon rainforest, by comparing the planning used in a forest management unit with ILP and Multi-Objective Evolutionary Algorithm (MOEA) methods. The main contribution is to provide a number of flexible responses to the same problem, a fact not usually observed in exact resolution methods, allowing the selection of options at each favorable time of forest planning.

\section{MATERIAL AND METHODS}

\subsection{Problem description}

In order to carry out the sustainable forest management plan activities, it is necessary to follow certain criteria established by Normative Instruction n. 5, December 11, 2006 (Brasil, 2006). These criteria demand from the technical manager - a forest engineer - that the field team accomplishes the forest exploitation planning respecting current laws, in other words, causing minimal damage to the forest. Thus, in order to reduce forest operations impacts, it is fundamental to define an ideal number of log decks in the forest management area.

The log decks number is directly related to whether it is capacitated facility location problem or not. The capacitated log desks consider the maximum amount of wood that can be stored in it, and only after the log decks have their full capacity filled, the stocked wood will be removed. The non-capacitated log deck has no storage limit because wood transport is carried out continuously. Thus, it is necessary to define the ideal number of log decks to be built in the managed area, since it implies the entire planning of forest exploitation area.

\subsection{Sustainable forest management plan}

The study was developed in a forest management unit named "Cipoal Farm". This unit was divided

Revista Árvore 2021;45:e4506 
into area 1 (189.19 ha) and area $2(2,609.22 \mathrm{ha})$. Both present vegetation consisting of open tropical rainforest, with the presence of trees, bamboos, and palm trees (Acre, 2010). Besides, "Cipoal Farm" is predominantly characterized by a flat terrain composed of argisol (Acre, 2010). Timber transportation took place through forest roads; furthermore, the farm has easy access to BR-364 near the Rio Branco timber processing center. The forest inventory was started with the marking and the numbering of trees in aluminum tags. Subsequently, the botanical identification of the individuals, the measurement of diameter at breast height (DBH) and commercial height, and the quality of the stem were determined. Finally, the individuals were georeferenced.

To simulate the location of log decks, points were generated every $50 \mathrm{~m}$ along the forest road, considering only its layout, that is, the forest road established in forest planning, in a Geographic Information System (GIS). These geo-referenced points were considered as the center of the log decks.

In order to solve the problem, in the capacitated and non-capacitated forms, two approaches were used, one exact and the other approximate, using the integer linear programming (ILP) and the multiobjective evolutionary algorithms (MOEA).

\subsection{Integer linear programming}

The proposed model for ILP solution was based on a mathematical model formulated to solve the problem of p-medians. In this approach, the proposed objective-function was to reduce the skidding to $\log$ decks. Thus, the objective-function (1) seeks to reduce the sum of the displacement of the $N \operatorname{logs} i$ to the $P$ decks $j$, where the displacement was represented by the Euclidean distance, defined as a linear metric measure. The restrictions used were: (2) selection of logs $i$ to be directed to a single deck $j$, (3) exclusive log skidding to a single deck, (4) restriction defining the number of decks to be installed for log storage (ND), (5) restriction defining the maximum capacity of $10 \mathrm{~g}$ storage (capacitated form), defined as $\mathrm{V}_{\mathrm{J}}=1.000 \mathrm{~m}^{3}$ according to Martinhago (2012), (6) condition that guarantees only the use of binary decision variables $\{0,1\}$ :

$\operatorname{Min} Z=\sum_{i=1}^{N} \sum_{j=1}^{D} C_{i j} x_{i j}$

Eq. 1

$\sum_{j=1}^{D} x_{i j}=1, \forall_{i}$

Eq. 2 $x_{i j} \leq y_{j}, \forall_{i}, \forall_{j}$

Eq. 3

$\sum_{j=1}^{D} y_{j}=N D$

Eq. 4

$\sum_{i=1}^{N} V_{i j} x_{i j} \leq V_{j}, \forall_{j}$

Eq. 5

$x_{i j}=\{0,1\}, y_{j}=\{0,1\}, \forall_{i}, \forall_{j}$

Eq.6

Where: $Z=$ vector resulting from the sum of $\log$ displacement $i$ to the decks $j ; \mathrm{x}_{\mathrm{ij}}=$ binary decision variable $\{0,1\}$ used to displace the $\log i$ to the decks $j ; \mathrm{y}_{\mathrm{j}}=$ binary decision variable $\{0,1\}$ used to activate the deck $j ; \mathrm{v}_{\mathrm{ij}}=$ individual merchantable volume with bark $\left(\mathrm{m}^{3}\right)$ of the $\log i$ allocated to the $\operatorname{deck} j$; ND $=$ number of decks to be capacitated; $\mathrm{c}_{\mathrm{ij}}=$ skidding cost in meters (Euclidean distance) between $\log i$ and deck $j$, where $i=\{1,2, \ldots, 900\} ; \mathrm{J}=\{1,2, \ldots, 30\}$.

The ILP mathematical model was formulated and processed in the Language for Interactive General Optimizer (LINGO) software (Lindo, 2015), version 16.0, on a computer with Intel ${ }^{\circledR}$ Core $^{\mathrm{TM}}$ i3 $3.10 \mathrm{GHz}$ processor and $8 \mathrm{~Gb}$ of RAM.

\subsection{Multi-objective evolutionary algorithm}

In MOEA approach, a vector optimization problem was elaborated formed by two conflicting objectives: i. to reduce log skidding to the respective deck; ii. to reduce the number of capacitated decks (ND). This problem was written according to Equations 7 and 8, subjected to the same restrictions presented in ILP approach, excepted for Equation 4, which in this proposal became one of the objectives to be reduced. In this situation, from the moment that a deck becomes capacitated, the trees less distance from the deck are assigned to this deck, provided that it does not exceed the allowed volume (capacitated form).

$$
\begin{array}{ll}
\operatorname{MinZ}=\sum_{i=1}^{D} \sum_{j=1}^{N} c_{i j} x_{i j} & \text { Eq.7 } \\
\operatorname{Min} N D=\sum_{j=1}^{D} y_{j} & \text { Eq.8 }
\end{array}
$$

Where: $Z=$ vector resulting from the sum of $\log$ displacement $i$ to the decks $j ; \mathrm{x}_{\mathrm{ij}}=$ binary decision variable $\{0,1\}$ used to displace the $\log i$ to the decks $j ; \mathrm{y}_{\mathrm{j}}=$ binary decision variable $\{0,1\}$ used to activate the deck $(j) ; \mathrm{ND}=$ number of decks to be capacitated; $\mathrm{c}_{\mathrm{ij}}=$ displacement in meters cost (Euclidean distance) between $\log i$ and deck $j$, where $\mathrm{i}=\{1,2, \ldots, 900\} ; \mathrm{J}=$ $\{1,2, \ldots, 30\}$.

For bi-objective problem solving, it was used the Improved Nondominated Sorting Genetic Algorithm 
Source: From the authors.

Fonte: Dos Autores

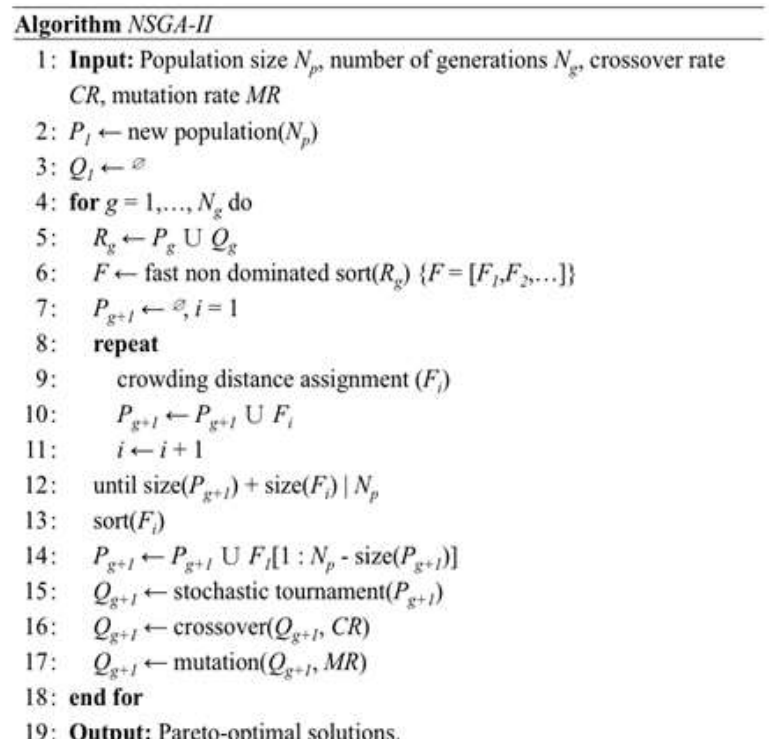

Figure 1 - Improved Nondominated Sorting Genetic Algorithm (NSGA-II).

Figura 1 - Algoritmo Genético de Classificação por Não Dominância (NSGA-II).

(NSGA-II), proposed by Deb et al. (2002) (Figure 1). Although other evolutionary multiobjective optimization algorithms have been proposed for many-objective problems (3 or more objectives), the use of the NSGA-II is still recommended for two objectives optimization problems (Deb and Jain, 2014; Zhou et al, 2019).

In the first step of this algorithm, a population sized $N d$ with bit-string type individuals (binary coding) was created. Each individual has $D$ binary values corresponding to the activation or not of the $\log$ deck $j$. To make the algorithm more efficient, the initial population was created from the k-means clustering algorithm, using Euclidean distance as a metric. Thus, if the individual to be created has ND $=15$ (capacitated decks), the $\mathrm{k}$-means is executed to define 15 centroids according to the trees' location. Therefore, log decks whose coordinates are closest to the centroids are enabled.

After evaluating each individual through biobjective functions it was used the fast non dominated sort function, a procedure to classify the population in different non-dominance layers. First, the Pareto set is determined in the population $(F 1)$. Shortly after, individuals belonging to $F 1$ are excluded from the process and the next Pareto set is obtained (F2). This procedure is repeated until all individuals are sorted into one layer.

Since then, the crowding distance (CD) assignment function estimates the population solutions density around a particular solution taking the mean value of the distance between this solution and the two solutions on either side of it along each of the objectives (Deb et al., 2002). As well as the fast non dominated sort function, this function is fundamental for the selection procedure because it maintains a certain degree of diversity in the population.

The selection procedure is implemented by stochastic tournament, where two individuals are randomly chosen and the best one is selected, considering their non-dominance $(F)$ layer and the density of solutions around them. After this step, crossing operators (two cut-off points) and mutation (uniform) common to evolutionary algorithms (EA) are implemented and the algorithm is executed by $\mathrm{Ng}$ generations. NSGA-II was performed on a population of 300 individuals, 200 generations, crossover probability equal to 0.9 , and mutation probability equal to 0.1 .

The minimum number of $\log$ decks for capacitated form was defined considering the total volume of trees to be harvested and the total volume capacity of each deck. Thus, for area 1 and area 2 , the minimum numbers of decks to be activated in 6 units and 52 units, respectively, were defined. Their maximum values were equal to 30 units and 150 units, in this order. These values were attributed following the recommendation of Braz and Oliveira (2001) who reported that a viable distance for log dragging should be established between $150 \mathrm{~m}$ to $200 \mathrm{~m}$, and it can be extended up to a maximum of $400 \mathrm{~m}$ in order to not compromise the log dragging operation performed by the Skidder (forestry tractor), which could cause an increase in the operation cost.

\subsection{ILP and MOEA comparison}

In area 1 , the ILP and MOEA methods were compared to the current planning used in the forest management unit, where 1 to $30 \log$ decks were considered, for the not capacitated problem.

For area 2, only the MOEA method was implemented and compared to the current planning

Revista Árvore 2021;45:e4506 
used in the forest management unit. In this case, only the capacitated problem was undertaken. The decks' location total number was 871 and trees number was 8,319 , which makes this combinatorial optimization problem quite complex. In order to carry out the comparison, the minimum value of 52 and the maximum of 150 decks were considered. For this example, the size of the population was 2,000 individuals and 1,000 generations, and the remaining configuration was equal to the previous problem of area 1 .

The NSGA-II algorithm was implemented using Matlab software (Matlab, 2011), version R2011b. The exploration maps were performed in ArcMap software (Esri, 2015), version 10.3. The results figures were created in the free software Gimp, version 2.8.20 (Gimp, 2020).

\section{RESULTS}

In area 1, it was found that MOEA obtained results close to the ILP (mean percentage error of $0.29 \%$ ), as can be seen by the solutions of both presented in (Figure 2). When comparing the number

Source: From the authors.

Fonte: Dos Autores
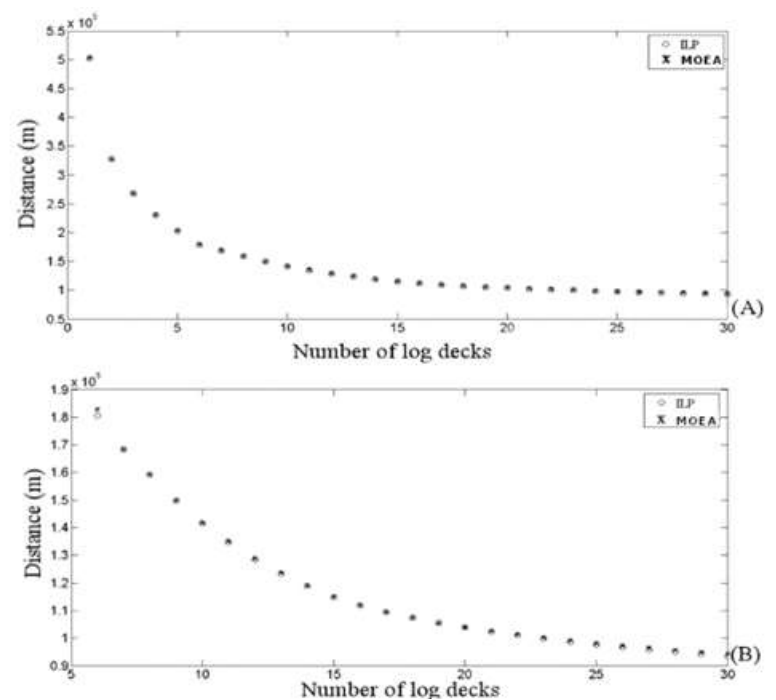

Figure 2 - Results obtained by ILP (circles) and MOEA (markers) for the problem of reduced area of management, where: (A) non-capacitated problem and (B) capacitated problem.

Figura 2 -Resultados obtidos pela ILP (círculo) e MOEA (traçado) para o problema de área de manejo reduzida, em que: (A) problema não capacitado e (B) problema capacitado. of $\log$ decks to 6 and 13 decks, the results of the objective function were 180,631.80 $\mathrm{m}$ and 178,857.70 $\mathrm{m}$, capacitated and non-capacitated, respectively, for ILP. Meanwhile, the results of the MOEA were $182,904.31 \mathrm{~m}$ and $179,525.27 \mathrm{~m}$, capacitated and non-capacitated, respectively, concerning the results of ILP objective functions. The average processing time of ILP was $4 \mathrm{~min} 09 \mathrm{~s}$ and $1 \mathrm{~min} 01 \mathrm{~s}$, capacitated and non-capacitated, respectively, while MOEA was $46 \mathrm{~s}$ for capacitated and $30 \mathrm{~s}$ for non-capacitated form.

Subsequently, MOEA was performed for the entire area 2. The MOEA obtained solutions in an average time of $38.174 \mathrm{~s}$. The Pareto-optimal solutions obtained are presented in (Figure 3).

Comparing MOEA to the current planning used in the forest management unit (Table 1), a scenario with 119 active decks, a reduction of $5.80 \%$ in road sizing by MOEA were observed.

(Figure 4) shows the log decks allocation determined by MOEA, compared to the current planning performed in the field.

It should be noted that the proposed multiobjective evolutionary approach helps to reduce computational processing time (which made it feasible obtaining solutions in the total area), and assists the team responsible for the project to choose the most suitable alternative among several other management alternatives (through Pareto-optimal solutions), with more flexibility and technical-scientific support.

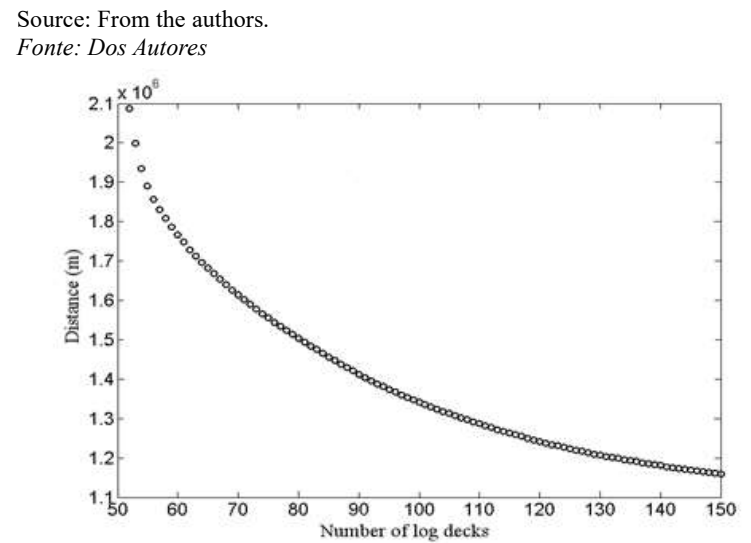

Figure 3 - Results of Pareto set obtained by MOEA for capacitated problem in a forest management unit, area 2.

Figura 3 - Resultados do conjunto de Pareto obtido pelo MOEA para o problema capacitado em uma unidade de manejo florestal, área 2.

\section{Revista Árvore 2021;45:e4506}


Table 1 - Comparison of solutions found by MOEA and the current planning performed in the field for road sizing

Tabela 1 - Comparação das soluções encontradas pelo MOEA e o planejamento executado em campo para o dimensionamento de estradas

\begin{tabular}{lccc}
\hline Method & Number of Log decks & Road sizing (m) & Road sizing reduction (\%) \\
\hline${ }^{*}$ PF & 119 & 43872.00 & - \\
\hline MOEA & 119 & 41329.43 & 5.80 \\
\hline
\end{tabular}

"Performed in the field.

"Realizado em campo.

\section{DISCUSSION}

Unlike the ILP that considers optimal solution, the MOEA presents the results according to the Pareto solution, in which the best results are shown, allowing the selection of those that aid in the decision-making in planning.

Comparing the MOEA to ILP, it can be observed (Figure 2) they are close to the optimal solution for

Source: From the authors. Fonte: Dos Autores

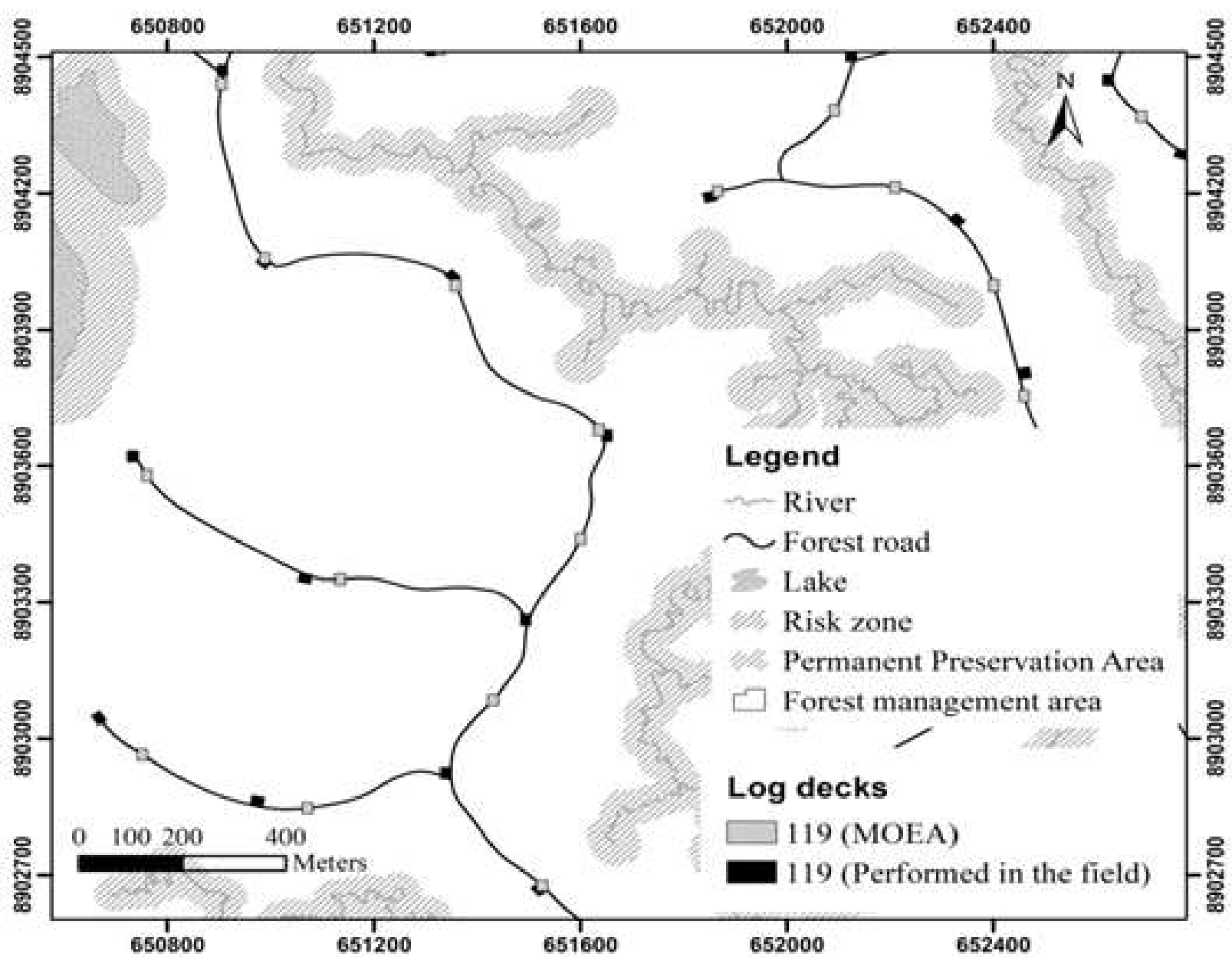

Figure 4 - Comparison of MOEA and the current planning performed in the field for forest road sizing in a scenario of 119 log decks.

Figura 4 - Comparação do MOEA e o planejamento atual executado em campo para dimensionamento de estradas florestais em um cenário de 119 pátios de estocagem de madeira. 
capacitated and non-capacitated problems. The mean percentage error was $0.29 \%$ of MOEA concerning the ILP. Nascimento et al. (2012) obtained the best solution with Particle Swarm Optimization (PSO) algorithm with the gbest topology concerning the ibest topology. The result considering the gbest topology was $99.07 \%$ of optimal forest planning but did not present satisfactory results concerning the mean and the minimum value. Liu and Lin (2015) proposed the use of Cultural algorithm to maximize the total volume in logging and they got better results of $0.44 \%$ and $1.13 \%$ concerning the Simulated Annealing (SA) algorithm.

MOEA processing time was better than the ILP. However, it should be noted that the MOEA present several results simultaneously, which does not occur with ILP. Gomide et al. (2013) observed that, by improving the configuration of AS metaheuristic, it was possible to improve processing time and to obtain results close to the optimal solution.

Observing area 2, MOEA presented better results regarding the reduction of log decks and, consequently, a reduction in road construction in the forest management area. However, the solution found by MOEA will no longer allocate log decks at strategic points in the forest management area, where the log could not be moved to the deck through protect areas, such as Permanent Preservation Areas (PPA).

It should be noted that the solution obtained by MOEA will only consider the road outlined in the forest management plan. Consequently, some restrictions on log deck allocation were not considered, such as bridges, PPA, sharp relief, swampy or rocky areas. However, MOEA presents high flexibility, allowing further inclusion of some conditions imposed by the forest, such as streams, fallen trees, and land slope in the optimization process, useful information for choosing the best number of log decks to be enabled.

The 119-log deck scenario generated by MOEA, unlike the current planning performed in the field, reduced their oversize, since it was possible to find a smaller number of capacitated decks. This scenario contributed to forest road reduction as well as the damages caused in remnants of native vegetation. As can be seen in (Figure 3), when considering 52, 60, 70, and $119 \log$ decks, there is a decrease in road sizing. Thus, the specialist can carry out a better planning for the forest management area, reducing the impacts generated by logging.

However, the presented results show that the NSGA-II algorithm obtained good solutions for the log/deck allocation problem. Proper planning, that is, proper log deck allocation, reduces the damage caused to the forest and allows the logging of remaining trees for the next forestry (Braz and Oliveira 2001).

The proposed evolutionary multi-objective approach enabled the reduction of computational processing time (which allowed the achievement of solutions in the whole area) as well as the presentation of several management alternatives (Pareto-optimal solutions) to the project manager, rendering the decision-making more flexible and well-supported. Medjibe and Putz (2012) affirm that lack of proper planning in logging (such as maps for log deck allocation, forest roads, and skidding tracks) results in damage to the forest.

Ducheyne et al. (2006) found that spatial analysis has a set of objective functions but, in some situations, the objectives may be conflicting. Therefore, these researchers realized that the multi-objective genetic algorithm implementation in spatial analysis with operational research is advantageous, as it allowed working with conflicting objectives between objective functions.

Fotakis et al. (2012) and Fotakis (2015) used a special approach with a multi-objective genetic algorithm in forest planning and they found better results regarding wood volume maximization, and sediment levels minimization.

\section{CONCLUSIONS}

MOEA presented satisfactory results when compared to ILP in a management problem for area 1. MOEA was also implemented for log deck allocation in a larger management area, where it was not possible to implement ILP due to a large number of decision variables. Thus, for both area 1 and area 2 the proposed approach was compared to the current planning performed in the field, which proved the efficiency of the algorithm since, for the same number of capacitated log decks, a smaller skidding was found. In addition, MOEA provides several other solutions, with a smaller number of capacitated log decks, promoting flexibility in decision-making. This

Revista Árvore 2021;45:e4506 
flexibility allows conditions imposed by the forest not considered during the optimization process that can be used to choose the best number of log decks to be enabled.

\section{ACKNOWLEDGMENTS}

This work was supported by Coordination for the Improvement of Higher Education Personnel (CAPES). The authors thank the University of Lavras for scientific support, especially the Forest Sciences Department and the Laboratory of Signal Processing from Engineering Department and Lindo Systems Inc.. This research did not receive any specific grant from funding agencies in the public, commercial, or not-for-profit sectors.

\section{AUTHOR CONTRIBUTIONS}

Marcos Antonio Isaac Júnior - organization, data processing with integer linear programming, analysis of results, and writing.Bruno Henrique Groenner Barbosa - data processing using the genetic algorithm, and review.Lucas Rezende Gomide - methodological design, analysis of results, and review.Natalino Calegario - methodological design, analysis of results, and review.Evandro Orfanó Figueiredo - availability of the database, analysis of results, and review. Luiz Otávio Moras Filho - bibliographic research, discussion of results, revision, and translation.Elliezer de Almeida Melo - bibliographic research, discussion of results, and review.Daniel Dantas - bibliographic research, discussion of results, and review.

\section{REFERENCES}

Acre. Governo do Estado do Acre. Zoneamento Ecológico-Econômico do Estado do Acre Fase II (1:250.000): Documento Síntese. Rio Branco: SEMA; 2010. [cited 2019 March 1]. Available from: http://www.amazonia.cnptia.embrapa.br/ publicacoes_estados/Acre/Fase\%202/Documento_ Sintese.pdf/.

Álvarez-Miranda E, Garcia-Gonzalo J, UlloaFierro F, Weintraub A, Barreiro S. A multicriteria optimization model for sustainable forest management under climate change uncertainty: An application in Portugal. European Journal of Operational Research. 2018; 269(1):79-98. doi:10.1016/j.ejor.2017.04.052.
Boussaïd I, Lepagnot J, Siarry, PA. Survey on optimization metaheuristics. Information Sciences. 2013;237: 82-117.doi: 10.1016/j.ins.2013.02.041.

Brasil. Instrução Normativa n. 5, de 11 de dez. de 2006. Dispõe sobre procedimentos técnicos para elaboração, apresentação, execução e avaliação técnica de Planos de Manejo Florestal SustentávelPMFSs nas florestas primitivas e suas formas de sucessão na Amazônia Legal, e dá outras providências. Available from: https://www.mma.gov. br/estruturas/pnf/_arquivos/in\%20mma\%2005-06. pdf.

Brasil. Resolução n. 406, de 02 de fev. de 2009. Estabelece parâmetros técnicos a serem adotados na elaboração, apresentação, avaliação técnica e execução de Plano de Manejo Florestal Sustentável PMFS com fins madeireiros, para florestas nativas e suas formas de sucessão no bioma Amazônia. Available from: http://www2.mma.gov.br/port/ conama/legiabre.cfm?codlegi $=597$.

Braz EM, d'Oliveira MVN. Planejamento madeireira dentro dos critérios econômicos e ambientais. Circular Técnica No. 39/2001. Rio Branco, Acre: Embrapa. 2001. [cited 2019 May 1]. Available from: https://ainfo.cnptia.embrapa.br/digital/bitstream/ CPAF-AC/12476/1/cirtec39.pdf.

Deb K, Jain H. An Evolutionary ManyObjective Optimization Algorithm Using Reference-Point-Based Nondominated Sorting Approach, Part I: Solving Problems With Box Constraints. IEEE Transactions on Evolutionary Computation. 2014;18(4):577-601. doi:10.1109/ TEVC.2013.2281535.

Deb K, Agrawal S, Pratap A, Meyarivan, T. A Fast Elitist Non-dominated Sorting Genetic Algorithm for Multi-objective Optimization: NSGA-II. In Proceedings of 2002. IEEE Transactions on Evolutionary Computation. 2002;6:182-197.doi: 10.1007/3-540-45356-3_83.

Ducheyne EI, Wulf RR, Baets B. A spatial approach to forest-management optimization: linking GIS and multiple objective genetic algorithms. International Journal of Geographical Information Science. 2006;20(8):917-928. doi:10.1080/13658810600711287.

ESRI. ArcGIS Pro. Version 10.3. Redlands, CA:

Revista Árvore 2021;45:e4506 
Environmental Systems Research Institute; 2015.

Fotakis DG. Multi-objective spatial forest planning using self-organization. Ecological Informatics. 2015;29:1-5. doi:10.1016/j.forpol.2012.04.002.

Fotakis DG, Sidiropoulos E, Myronidis D, Ioannou K. Spatial genetic algorithm for multi-objective forest planning. Forest Policy and Economics. 2012;21:12-19. doi:10.1016/j.forpol.2012.04.002.

GIMP. Gnu Image Manipulation Program. Version 2.10.20. Available at: https://www.gimp.org; 2020.

Gomide LR, Arce JE, Silva ACL. Comparação entre a meta-heurística simulated annealing e a programação linear inteira no agendamento da colheita florestal com restrições de adjacência. Ciência Florestal. 2013;23: 449-460.doi: $10.5902 / 198050989289$.

Hernandez M, Gómez T, Molina J, León MA, Caballero, R. Efficiency in forest management: A multiobjective harvest scheduling model. Journal of Forest Economics. 2014;20(3):236-251. doi:10.1016/j.jfe.2014.06.002.

LINDO. Lingo: Language for Interactive General Optimizer. Version 16.0. Lindo System Inc; 2015.

Liu WY, Lin CC. Spatial forest resource planning using a cultural algorithm with problem-specific information. Environmental Modelling \& Software. 2015;71:126-137. doi: 10.1016/j.envsoft.2015.06.002

Maier HR, Kepelan Z, Kasprzyk J, Kollat J, Matott LS, Cunha MC, et al. Evolutionary algorithms and other metaheuristics in water resources: Current status, research challenges and future directions. Environmental Modelling \& Software. 2014;62:271299. doi:10.1016/j.envsoft.2014.09.013.

Martinhago AZ. Otimização para a locação de pátios de estocagem para exploração de impacto reduzido na Amazônia brasileira [Tese]. Lavras, MG: Universidade Federal de Lavras; 2012.

MATLAB. Version R2011b. Natick, Massachusetts: The MathWorks Inc.; 2011.

Medjibe VP, Putz FE. Cost comparisons of reducedimpact and conventional logging in the tropics. Journal of Forest Economics. 2012;18(3):242-256. doi:10.1016/j.jfe.2012.05.001.

Nascimento FAF, Dias AN, Figueiredo Filho A, Arce JE, Miranda GM. Uso da Meta-Heurística otimização por exame de partículas no planejamento Florestal. Scientia Forestalis. 2012;40(96):557-565.

Steiguer JE, Liberti L, Schuler A, Hansen B. Multi-criteria decision models for forestry and natural resources management: an annotated bibliography[Internet]. Newtown Square:USDA Forest Service; 2003. [cited 2019 July 06]. Available from: https://www.nrs.fs.fed.us/pubs/gtr/gtrne307. pdf.

Zhou J, Gao L, Yao X, Chan FTS, Zhang J, Li X, Lin Y. A decomposition and statistical learning based many-objective artificial bee colony optimizer. Information Sciences. 2019;496:82-108. doi:10.1016/j.ins.2019.05.014. 